\title{
Fire alters the availability of soil nutrients and accelerates growth of Eucalyptus grandis in Zambia
}

\author{
Donald Chungu $^{1,2} \cdot$ Phillimon Ng'andwe $^{1} \cdot$ Henry Mubanga ${ }^{1} \cdot$ Felix Chileshe $^{1}$
}

Received: 3 December 2018/ Accepted: 5 January 2019/Published online: 14 May 2019

(C) The Author(s) 2019

\begin{abstract}
Fire has been used to prepare land during tree plantation establishment for many years but uncertainty about how ecosystems respond to prescribed burning makes it difficult to predict the effects of fire on soil nutrients. The aim of this study was to determine the effect of burning accumulated forest residues (slash) on soil chemical properties and how trees respond. We analyzed 40 burned and unburned sites and compared growth of Eucalyptus grandis W. Hill ex Maiden between sites. Soil $\mathrm{pH}$ increased by $39 \%$ after fire, suggesting reduced soil acidity and increased liming. Total nitrogen increased by $100 \%$; other nutrients $\left(\mathrm{Ca}^{2+}, \mathrm{Mg}^{2+}\right.$ and $\left.\mathrm{K}^{+}\right)$also increased. Increase in nutrients had a significant effect on the growth of $E$. grandis; larger and taller trees were associated more with burned than unburned sites. This study provides evidence that burning accumulated slash during land preparation prior to plantation establishment alters soil nutrient status and enhances the growth of E. grandis.
\end{abstract}

Keywords Nitrogen mineralization - Forest residue burning $\cdot$ Soil nutrients $\cdot$ Zambia exotic plantations . Plantation establishment $\cdot$ Eucalyptus grandis

Project funding: This project was funded by Copperbelt University.

The online version is available at http://www.springerlink.com.

Corresponding editor: Zhu Hong.

Donald Chungu

donald.chungu@gmail.com; donald.chungu@cbu.ac.zm

1 School of Natural Resources, Copperbelt University, P.O. Box 21692, Kitwe, Zambia

2 Directorate of Distance Education and Open Learning, Copperbelt University, P.O. Box 21692, Kitwe, Zambia

\section{Introduction}

Fire has been used to prepare land for the establishment of tree plantations for many decades. However, fire can alter soil properties and influence tree growth (Tng et al. 2014). It sometimes has a fertilizing effect on both physical and chemical properties (Pyne 2001; Heydari et al. 2015; Nabatte and Nyombi 2013; Thomaz et al. 2014). This fertilizing effect led Knapp and Seastedt (1986) and Ojima et al. (1994) to propose the nitrogen mineralization hypothesis, that nitrogen $(\mathrm{N})$ availability is elevated following fire. Since plant growth increases with available $\mathrm{N}$ (Yafei et al. 2015), in this study we expect increased growth of Eucalyptus grandis on burned sites compared to unburned sites.

Several studies have shown that during the first few years following burning, labile nitrogen in soil was higher on burned than on unburned sections of the forest (Certini 2005; James et al. 2018). Ammonium and nitrates, the main sources of nitrogen for plants, often increase after fire because ammonium is released from organic matter due to heating, and the nitrification process is often stimulated (Wan et al. 2001). Biological processes are responsible for the release of nitrogen confined in unburned soils and litter. Hart et al. (2005) observed that surviving fungi in the soil after fire become functionally more diverse, and certain nitrifying bacteria increase 10 times more than levels in unburned forests, thereby increasing soil nitrate levels.

Soil acidity contributes to nutrient deficiencies or to toxic conditions that could retard tree growth. For example, the toxicity of aluminum ( $\mathrm{Al})$ associated with acid soils is one of the common and severest problems of tropical soils (Rout et al. 2001). This suggests that $\mathrm{Al}$ toxicity increases with soil acidity, and high Al levels negatively affect the bacteria involved in the N cycle (Rout et al. 2001; Pietri 
and Brookes 2008). However, following a fire, ash is deposited on the forest floor and $\mathrm{pH}$ increases, thereby decreasing soil acidity (Kim et al. 2011; Nabatte and Nyombi 2013; Xue et al. 2014) and preventing Al toxicity and other problems associated with acid soils. The increase in soil $\mathrm{pH}$ (a liming effect), has a positive impact on the biological recovery of soils after fire (Pietri and Bookes 2008), and has been attributed to the accumulation of hydroxides of $\mathrm{K}$ and $\mathrm{Na}$, and oxides and carbonates of $\mathrm{Mg}$ and $\mathrm{Ca}$ (Sanchez 2019). Furthermore, ash contains large quantities of essential micronutrients which enhance plant growth and contribute to forest productivity (Arocena and Opio 2003; Neff et al. 2005).

Although fire may have a positive influence on the soil, divergent conclusions have been reported (Neff et al. 2005; Verma and Jayakumar 2012; Heydari et al. 2015), suggesting that the question of how fire affects soils and plant growth has not been answered. Fire has decreased soil nutrients through volatilization (Zhao et al. 2015). Inbar et al. (2014) reported a significant decrease of organic matter in the soil following a severe fire, which adversely affected chemical, physical and microbiological properties (Antoine et al. 2013; Zhao et al. 2015). Decreases in soil organic $\mathrm{N}$ and $\mathrm{C}$ have also been observed after fire (Murphy et al. 2006). Depending on the intensity of fire, soil organic C may increase or decrease (Neff et al. 2005). Increase in bulk density has been reported with a decrease in soil moisture following a fire (Yildiz et al. 2010; Xue et al. 2014). The collapse of organo-mineral aggregates and clogging of soil pores by ash or free clay minerals have been implicated in the increase of bulk density after fire (Alcañiz et al. 2018). This implies a decrease in the water holding capacity and consequently accelerating runoff and surface erosion (Martin and Moody 2001) which adversely affects growth.

The aim of this study was to determine the influence of fire during land preparation for Eucalyptus plantation establishment. The following questions were addressed: (1) Does burning accumulated organic matter increase total- $\mathrm{N}$ and essential micronutrients? and (2) Is the growth of $E$. Grandis enhanced after fire?

\section{Materials and methods}

To answer these questions, soils were sampled on burned and unburned sites to determine their characteristics. Stem diameter, height and other parameters for $E$. Grandis were assessed to determine whether there was a significant difference in growth between burned and unburned sites.

\section{Study site}

The study was carried out in E. Grandis plantations in Shiwang' andu district $\left(11^{\circ} 32^{\prime} \mathrm{S}\right.$ and $\left.31^{\circ} 81^{\prime} \mathrm{E}\right)$ in Muchinga province, approximately $740 \mathrm{~km}$ north of Lusaka, Zambia. Climate is typical of a savannah, characterized by three seasons: hot dry (September-November), hot wet (December-April) and cool dry (May-August). The lowest mean temperature $\left(15^{\circ} \mathrm{C}\right)$ is usually in June or July and the highest $\left(28{ }^{\circ} \mathrm{C}\right)$ in October. Shiwang' andu lies in a high rainfall region, receiving over $1200 \mathrm{~mm}$ annually. The area is part of the Central African Plateau and soils are Acrisols, highly leached and acidic. The vegetation is mixed indigenous forests of mainly Brachystegia, Julbernardia and Isoberlinia species, characteristic of typical wet miombo woodlands.

\section{Experimental design and data collection}

Eucalyptusgrandis plantations in Shiwang' andu were established in January 2015 on land previously covered by mixed indigenous forests characterized with 37.2 tons ha $^{-1}$ of biomass (Shakacite et al. 2016). Site preparation followed clearing of indigenous forests. The felled trees, branches, leaves (forest residue or slash) were piled in windrows approximately $20 \mathrm{~m}$ wide and $100 \mathrm{~m}$ long and varied, depending on the size of plantation under preparation. The distance between two consecutive windrows was approximately $30 \mathrm{~m}$. Windrows were left to dry for three months before burning thoroughly to ash before the onset of the rainy season. Clearing before plantation establishment resulted in the removal or redistribution of substantial nutrients from the forest floor to accumulate in the windrows. In addition, removal of slash caused an impoverishment of nutrients in the non-windrow areas (Achat et al. 2015). Burning forest residue caused rapid mineralization of nutrients immobilized in the vegetation, increasing the concentration of nutrients in the soil under the windrows. For the purpose of this study, the sections covered by windrows were classified 'burned sites' and areas between two consecutive windrows were 'unburned sites'. E. Grandis was planted to establish plantations of various sizes on the prepared land. No fertilizer was added at planting time or during the study period. In January 2016 (1 year after the fire), 20 random $12 \mathrm{~m} \times 12 \mathrm{~m}$ plots were established on burned sites and 20 plots on unburned sites, and data collected. In January 2018 (3 years after the fire), data collection in the same plots was repeated. There were 16 trees in each plot, 640 trees in total for analysis.

Diameter $(\mathrm{cm}) 30 \mathrm{~cm}$ above ground using a caliper and height $(\mathrm{m})$ were recorded for each tree (Shakacite et al. 2016). Stem diameter and height measurements were done in 2016 and repeated in 2018. To assess bark thickness and 
wood density, two cores were extracted from each tree, one at $25 \mathrm{~cm}$ and the other $30 \mathrm{~cm}$ above the ground using a Haglöf Increment Borer $4.3 \mathrm{~mm}$ diameter (Västernorrland, Sweden). Each core was placed into a plastic straw, the ends sealed and labelled. All wood cores were transported in a cooler box to the laboratory at the Copperbelt University, Kitwe for analyses. Each sample consisted of bark, xylem and pith. Samples were oven-dried at $103{ }^{\circ} \mathrm{C}$ for $48 \mathrm{~h}$ and measurements corrected to $12 \%$ moisture content. A distinct bark section from each core was measured with a digital veneer caliper to the accuracy of $0.1 \mathrm{~mm}$. Two measurements (i.e., responding to the two core samples per tree) were averaged to obtain bark thickness. For each core, length and diameter were measured at different points with a caliper to get average diameter to calculate volume $\left(\mathrm{cm}^{3}\right)$ using the standard formula for a cylinder. To determine wood density, weight for each core was measured to the nearest $0.01 \mathrm{~g}$ and divided by its volume. Both bark thickness and wood density were assessed only for the 3-year-old saplings.

\section{Soil sampling}

Soil bulk density of the $30 \mathrm{~cm}$ surface layer was determined using the core method and expressed in $\mathrm{g} \mathrm{cm}^{-3}$ (Grossman and Reinsch 2002). To assess chemical properties, five samples from each plot were randomly collected using a $10-\mathrm{cm}$ auger, separately packaged and transported to the laboratory. Each sample was passed through a 2-mm sieve. Soil $\mathrm{pH}$ was measured using a multi $3320 \mathrm{pH}$ meter (Adamchuk et al. 1999). Total nitrogen was determined by Kjeldahl oxidation and semi-micro Kjeldahl distillation (Bremner 1960), and expressed as a percentage. Exchangeable calcium $\left(\mathrm{Ca}^{2+}\right)$ and magnesium $\left(\mathrm{Mg}^{2+}\right)$ were determined by the complexometric titration method using ethylene diamine tetra acetic acid, and available potassium $\left(\mathrm{K}^{+}\right)$was extracted using the Mehlich-3 method (Mehlich 1984). Calcium, $\mathrm{Mg}^{2+}$ and $\mathrm{K}^{+}$were expressed in milliequivalents $(\mathrm{mEq})$. The total content of elemental phosphorus (P) was extracted using Bray and Kurtz (1945) expressed in parts per million (ppm). Soil organic matter was determined by the Walkley and Black method and expressed as a percentage. Soil assessment was carried out in 2016 and repeated in 2018 when E. Grandis saplings were 1-year-old and 3-years-old, respectively.

\section{Data analysis}

Mean values per plot for diameter, height, bark thickness and wood density were calculated and used as metrics for tree growth in burned and unburned sites. This was repeated for total $\mathrm{N}$, soil organic matter, and $\mathrm{pH}, \mathrm{Ca}^{2+}, \mathrm{K}^{+}, \mathrm{P}$ and $\mathrm{Mg}^{2+}$. The strength of the relationship between growth parameters and soil characteristics was determined using Pearson correlation coefficients. To assess the effect of altering soil characteristics by fire on $E$. Grandis, each tree growth parameter was expressed as a function of total $\mathrm{N}$, soil organic matter, $\mathrm{pH}, \mathrm{Ca}^{2+}, \mathrm{K}^{+}$and $\mathrm{P}$ as a linear regression. Student $t$ test was used to determine a difference in growth of $E$. Grandis between burned and unburned sites. All analyses were done in R software.

\section{Results and discussion}

This study found that total-N increased after fire and enhanced the growth of E. Grandis, and saplings on the burned sites, were significantly taller and larger than saplings on unburned sites. This suggests that the accumulation and burning of forest residues has a positive effect on young E. Grandis. This contradicts several studies that have reported that burning increased $\mathrm{N}$ volatilization, resulting in significant nitrogen loss from soil (Turner et al. 1997; Bond and Keeley 2005). Trees growing on such sites are deprived of $\mathrm{N}$, thereby negatively affecting plant growth (Otterstrom et al. 2006; Lawes and Clarke 2011). Furthermore, fast-growing E. Grandis saplings on burned sites had lower wood density than the slower growing $E$. Grandis on unburned sites (Fig. 1). This supports the observation that wood density decreases with increased rate of growth in planted Eucalyptus spp. (Bhat et al. 2007; DeBell et al. 2007).

\section{Bulk density, pH and organic matter}

Bulk density on burned sites ranged from $1.21-1.25 \mathrm{~g} \mathrm{~cm}^{-3}$ compared to bulk density range $1.20-1.25 \mathrm{~g} \mathrm{~cm}^{-3}$ on the unburned sites. Similar results were detected in 2015 before piling slash in windrows. Soil bulk density less than $1.5 \mathrm{~g} \mathrm{~cm}^{-3}$ has an optimum movement of air and water for similar soil types and is considered to be good soil for plant growth (Hunt and Gilkes 1992). Bulk density did not significantly differ between 2016 and 2018 assessments or between burned and unburned sites (Table 1), suggesting that it remains unaltered after fire, contrasting the observation by several researchers that burning increases bulk density and reduces moisture content (Hubbert et al. 2006; Boerner et al. 2009; Xue et al. 2014).

Mean soil pH on burned sites in 2016 was 6.1 compared to 4.5 on unburned sites. This was similar for the 2018 assessment where $\mathrm{pH}$ significantly increased by $39 \% 3$ years after fire in burned sites $(p \leq 0.001)$. Generally, $\mathrm{pH}$ remained below 5.0 on unburned sites while on burned sites it remained above 6.5 during the assessment period (Table 1), suggesting that burning decreases soil acidity. 
(a)

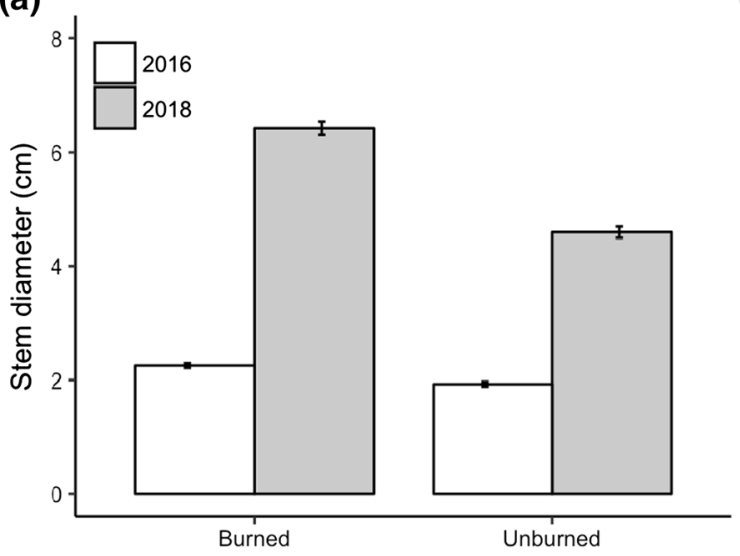

(c)

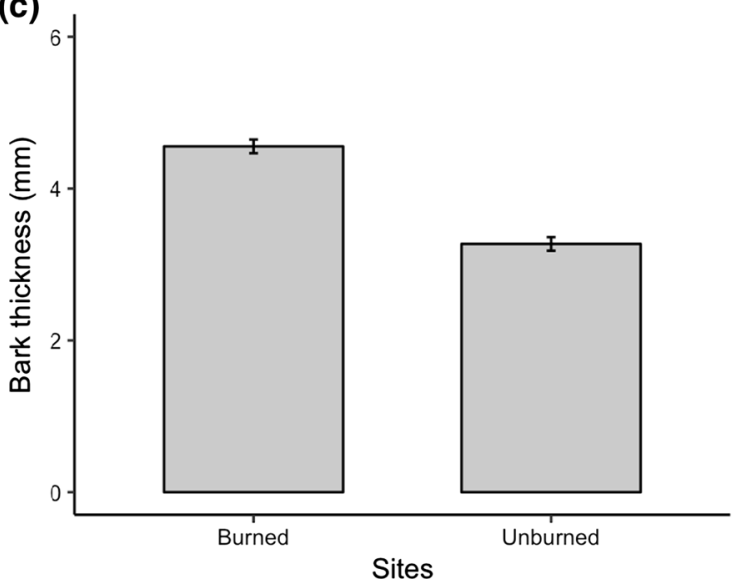

(b)

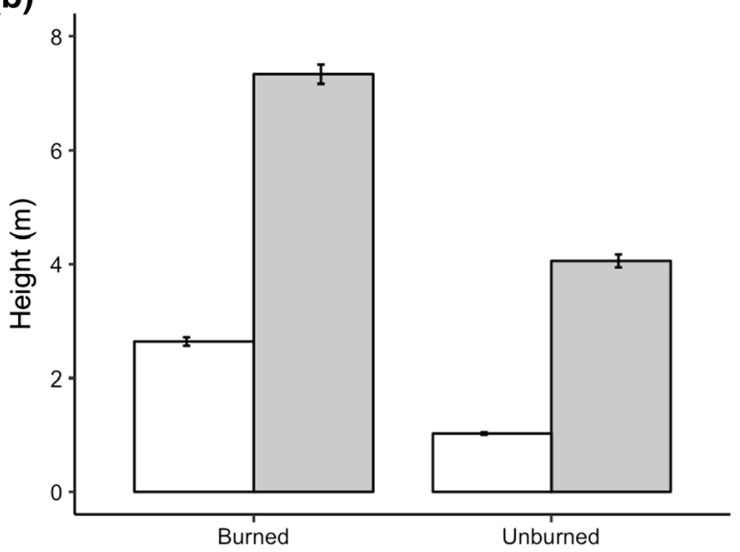

(d)

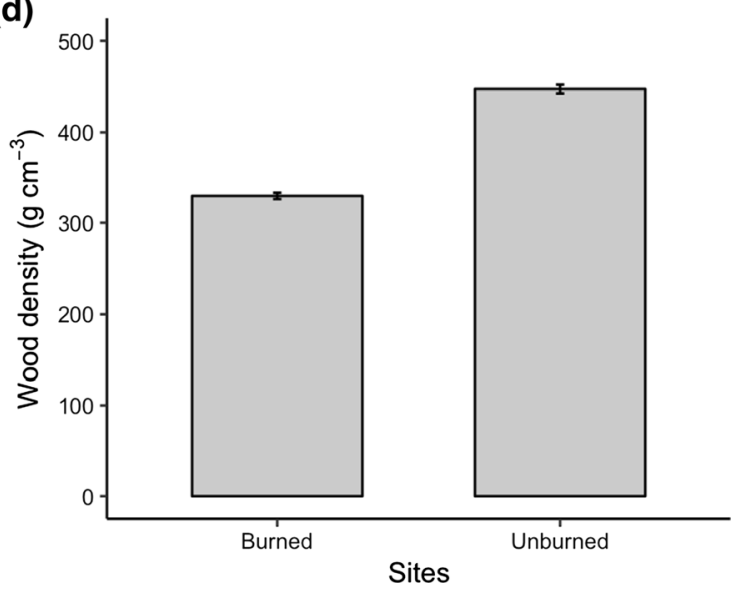

Fig. 1 Growth of E. Grandis on burned and unburned sites in Zambia; a stem diameter $(\mathrm{cm})$, b height $(\mathrm{m})$, $\mathbf{c}$ bark thickness (mm), and d wood density $\left(\mathrm{g} \mathrm{cm}^{-3}\right)$

Increase in $\mathrm{pH}$ after burning is due to the release of alkaline cations such as $\mathrm{Ca}^{2+}$ and $\mathrm{Mg}^{2+}$ (Certini 2005; Santana et al. 2018). A significant increase in $\mathrm{pH}$ as a result of burning occurs only at high temperatures as a result of the complete combustion of vegetative residues and is well correlated with concentrations of $\mathrm{Ca}^{2+}, \mathrm{Mg}^{2+}$ and $\mathrm{K}^{+}$ (Khanna et al. 1994; Arocena and Opio 2003).

Similarly, soil organic matter on unburned sites was $1.1 \%$ compared to $1.5 \%$ on burned sites 1 year after fire (2016 assessment). Three years later (2018 assessment), organic matter was $1.2 \%$ on unburned sites and to $2.0 \%$ on burned sites. Increased soil organic matter on burned sites was expected because residues accumulated during the piling of felled trees and other slash. The rate of increase in organic matter on burned sites was statistically significant (1.5 to $2.0 \%, 15 \%$ per year, $p \leq 0.001)$ and higher than on unburned sites (1.1 to $1.2 \%, 2.6 \%$ per year, $p=0.434$ ). Overall, soil organic matter on burned sites increased by $32 \%$ and $72 \%$ 1-year and 3-years after fire, respectively (Table 1). Several studies have found similar results where organic matter increased after fire (González-Pérez et al. 2004; James et al. 2019). There was also a positive correlation between $\mathrm{pH}$ and organic matter $(r=0.82, p$ $\leq 0.01$ ), suggesting that organic matter increased with $\mathrm{pH}$. An increase in $\mathrm{pH}$ by 0.5 units would lead to increases of about $50 \%$ in organic matter, and has been linked to increased microbial activity (Kalbitz et al. 2000). For example, earthworm activity increases with $\mathrm{pH}$ and has significant effects on organic matter. Earthworms ingest large quantities of soil and plant debris, releasing substantial excreta, thereby increasing organic matter (Kalbitz et al. 2000). Furthermore, increases in $\mathrm{pH}$ increases the amount of negatively-charged groups on humus colloids and therefore soil organic matter increases (Andersson et al. 2000; Kemmitt et al. 2006).

\section{Stocks of soil nutrients}

One year after fire, $\mathrm{K}^{+}$increased 2.5 times from $22.5 \mathrm{mEq}$ on unburned sites to $57.0 \mathrm{mEq}$ on burned sites $(p \leq 0.001)$. A similar trend was for $\mathrm{Ca}^{2+}(+20 \%, p \leq 0.001)$, P $(+9 \%, p \leq 0.05)$ and $\mathrm{Mg}^{2+}(+51 \%, p \leq 0.001)$, where concentrations on burned areas were significantly higher than on unburned sites (Table 1). Forest residues or slash 
Table 1 Changes in soil chemical characteristics after fire. Mean and standard error are shown. Changes in variables are + for increase, - for decrease between 2016 and 2018

\begin{tabular}{|c|c|c|c|c|c|c|c|}
\hline \multirow[t]{2}{*}{ Variable } & \multirow[t]{2}{*}{ Year } & \multicolumn{3}{|l|}{ Unburned plots } & \multicolumn{3}{|l|}{ Burned plots } \\
\hline & & Mean $\pm \mathrm{SE}$ & Change & $p$ value & Mean $\pm \mathrm{SE}$ & Change & $p$ value \\
\hline \multirow[t]{3}{*}{$\mathrm{K}^{+}$} & 2015 & $21.7 \pm 0.37$ & & & $22.1 \pm 0.33$ & & \\
\hline & 2016 & $22.5 \pm 0.29$ & - & 0.001 & $57.0 \pm 0.49$ & - & 0.001 \\
\hline & 2018 & $11.6 \pm 0.66$ & & & $27.3 \pm 1.60$ & & \\
\hline \multirow[t]{3}{*}{$\mathrm{P}$} & 2015 & $523.3 \pm 1.55$ & & & $522.6 \pm 1.71$ & & \\
\hline & 2016 & $527.6 \pm 1.79$ & - & 0.001 & $577.6 \pm 1.12$ & - & 0.031 \\
\hline & 2018 & $454.3 \pm 12.1$ & & & $517.4 \pm 18.4$ & & \\
\hline \multirow[t]{3}{*}{ Soil organic matter } & 2015 & $1.15 \pm 0.01$ & & & $1.15 \pm 0.01$ & & \\
\hline & 2016 & $1.14 \pm 0.01$ & + & 0.434 & $1.52 \pm 0.04$ & + & 0.001 \\
\hline & 2018 & $1.22 \pm 0.06$ & & & $1.98 \pm 0.06$ & & \\
\hline \multirow[t]{3}{*}{ Soil pH } & 2015 & $4.48 \pm 0.05$ & & & $4.49 \pm 0.04$ & & \\
\hline & 2016 & $4.51 \pm 0.04$ & + & 0.001 & $6.13 \pm 0.05$ & + & 0.029 \\
\hline & 2018 & $4.68 \pm 0.07$ & & & $6.52 \pm 0.16$ & & \\
\hline \multirow[t]{3}{*}{ Total-N } & 2015 & $0.02 \pm 0.001$ & & & $0.02 \pm 0.001$ & & \\
\hline & 2016 & $0.02 \pm 0.001$ & + & 0.001 & $0.043 \pm 0.004$ & + & 0.001 \\
\hline & 2018 & $0.03 \pm 0.003$ & & & $0.157 \pm 0.003$ & & \\
\hline \multirow[t]{3}{*}{$\mathrm{Ca}^{2+}$} & 2015 & $3.97 \pm 0.04$ & & & $4.02 \pm 0.05$ & & \\
\hline & 2016 & $4.01 \pm 0.03$ & - & 0.001 & $4.82 \pm 0.07$ & - & 0.001 \\
\hline & 2018 & $0.20 \pm 0.01$ & & & $0.22 \pm 0.01$ & & \\
\hline \multirow[t]{3}{*}{$\mathrm{Mg}^{2+}$} & 2015 & $6.44 \pm 0.06$ & & & $6.42 \pm 0.04$ & & \\
\hline & 2016 & $6.46 \pm 0.04$ & - & 0.001 & $9.74 \pm 0.07$ & - & 0.001 \\
\hline & 2018 & $0.21 \pm 0.01$ & & & $0.25 \pm 0.02$ & & \\
\hline
\end{tabular}

contained substantial quantities of nutrients; therefore the higher levels of nutrients in the burned sites is not surprising. The availability of these nutrients increased through the combustion of residues and organic matter (Certini 2005). In other studies, one month after a fire, available $\mathrm{Ca}^{2+}, \mathrm{Mg}^{2+}$, and $\mathrm{K}^{+}$in the soil of a Eucalyptus plantation were significantly higher than pre-fire levels, but three to six months later, the increases were almost gone (Tomkins et al. 1991; Santín et al. 2018). Our study, however, has shown that these nutrients can still persist even 1 year after fire, but this effect decline 3 years later (Table 1). The fact that the study area is in a high rainfall zone and soils are highly leached, decline in $\mathrm{Ca}^{2+}, \mathrm{Mg}^{2+}$, $\mathrm{K}^{+}$and P 3 years after fire could be attributed to leaching. Furthermore, high uptake of these nutrients by E. Grandis may have also contributed to the decline of these nutrients. More persistent fire- induced availability of these ions has also been reported elsewhere (Simard et al. 2001; Certini 2005)

Overall, total-N on the unburned sites was $0.02 \%$ compared to $0.04 \%$ on the burned sites, more than $100 \%$ increase after fire. Total-N on burned sites increased significantly by more than three times between 2016 and 2018 due to the accumulation of forest slash. Burning enhanced the release of nitrogen from the residues, increasing total-N content. Several studies have also reported an increase in nitrogen after fire (Andersson et al. 2000; Alcañiz et al. 2018; Pellegrini et al. 2018; Parro et al. 2019). Although P increased by $9 \%$ after fire, there was a slight decline in both sites between 2016 and 2018. On unburned sites, for example, $\mathrm{P}$ decreased from $527.6 \mathrm{ppm}$ in 2016 to 454.3 ppm in 2018, a $13.8 \%$ decline. While on burned sites, P decreased from 577.6 in 2016 to 517.4 in 2018, a $10.4 \%$ decline (Table 1). Net annual removal of nutrients from the soil has been reported to be significantly higher for P (i.e., approximately 30 times higher than $\mathrm{N}$ in $E u$ calyptus; Turner and Lambert 1983; de Dieu Nzila et al. 2002). The decline in phosphorous in this study is therefore not surprising. This is in agreement with the fact that $\mathrm{P}$ deficiency is a major factor limiting the growth of Eucalyptus species (Fisher and Binkley 2000; Graciano et al. 2005).

\section{Stem diameter and height}

A diameter range of 1.6-2.3 cm was observed for 1-year old E. Grandis saplings on burned sites compared to 1.4-2.0 cm for saplings on unburned sites (Fig. 1a, b). However, average diameter did not significantly differ between burned and the unburned sites for 1-year-old trees. Corresponding heights ranged from 2.0-2.6 m for saplings on burned sites compared to $0.9-1.4 \mathrm{~m}$ heights for 
saplings on the unburned sites. On average, 1-year-old $E$. Grandis on burned sites were significantly taller $(2.6 \pm 0.95 \mathrm{~m})$ than saplings on unburned sites $(1.0 \pm 0.30 \mathrm{~m} ; p \leq 0.05)$. This suggests that growth of 1-year-old E. Grandis height is stimulated more than diameter after fires.

At 3 years (2018 assessment), the mean stem diameter on burned sites was $6.4 \mathrm{~cm}$ compared to $4.6 \mathrm{~cm}$ on unburned sites $(p \leq 0.01)$. Height followed the same pattern where significantly taller saplings were on burned sites $(7.3 \mathrm{~m})$ than on unburned sites $(4.1 \mathrm{~m} ; p \leq 0.001)$. Overall, the frequency of taller and larger saplings was higher on burned sites than on unburned sites (Fig. 2). The differences in the growth on burned compared to unburned sites of E. Grandis was more distinct at 3 years than at 1 year and suggests that the effect of fire on growth is more pronounced few years after burning.

\section{Bark thickness and wood density}

In spite being the same age (3 years), trees on burned sites had thicker bark $(4.6 \mathrm{~mm})$ than trees on unburned sites (3.3 mm). Bark thickness in E. Grandis increased after fire ( $p \leq 0.01$, Fig. 1c). This result agrees with the observation that vigorously growing E. Grandis increases bark thickness along with diameter (Quilhó and Pereira 2001). Increase in bark thickness on burned sites in this study supports the observation that soil gains in $\mathrm{Ca}^{2+}, \mathrm{Mg}^{2+}$ and $\mathrm{K}^{+}$favor greater investment in bark thickness formation during early years of tree development (Fromm 2010; Paine et al. 2010). However, wood density for E. Grandis on burned sites was $329.65 \mathrm{~g} \mathrm{~cm}^{-3}$ compared to $446.76 \mathrm{~g} \mathrm{~cm}^{-3}$ on unburned sites, a $26 \%$ decrease in wood density. Generally, wood density of trees on unburned sites was significantly higher than wood density of trees on burned sites ( $p \leq 0.001$, Fig. 1d). In softwoods, increased growth rate produces wider growth rings, and narrower latewood than early wood, resulting in relatively low wood density (Saranpää 2003; Sopushynskyy et al. 2017). However, in hardwood plantations, including Eucalyptus spp., the effect of increased growth rate is still unclear (Saranpää 2003; Carrillo et al. 2015; Ko et al. 2017). In this study, slow growing trees on unburned sites had higher density than faster growing trees on burned sites, consistent with reports by King et al. (2006), Sotelo Montes et al. (2017), and Pretzsch et al. (2018). However, other studies did not find a relationship between rate of growth and wood density in Eucalyptus (Quilhó and Pereira 2001; Saranpää 2003).
Fig. 2 Histograms of mean height and diameter (logtransformed) across trees per plot. Note the clear difference between sites with taller and larger saplings on burned sites compared to unburned sites. The differences were tested using $t$ test (height: $t=14.71$, $d f=293.96, p<0.0001$; diameter: $t=11.09$, $d f=316.77, p<0.0001)$
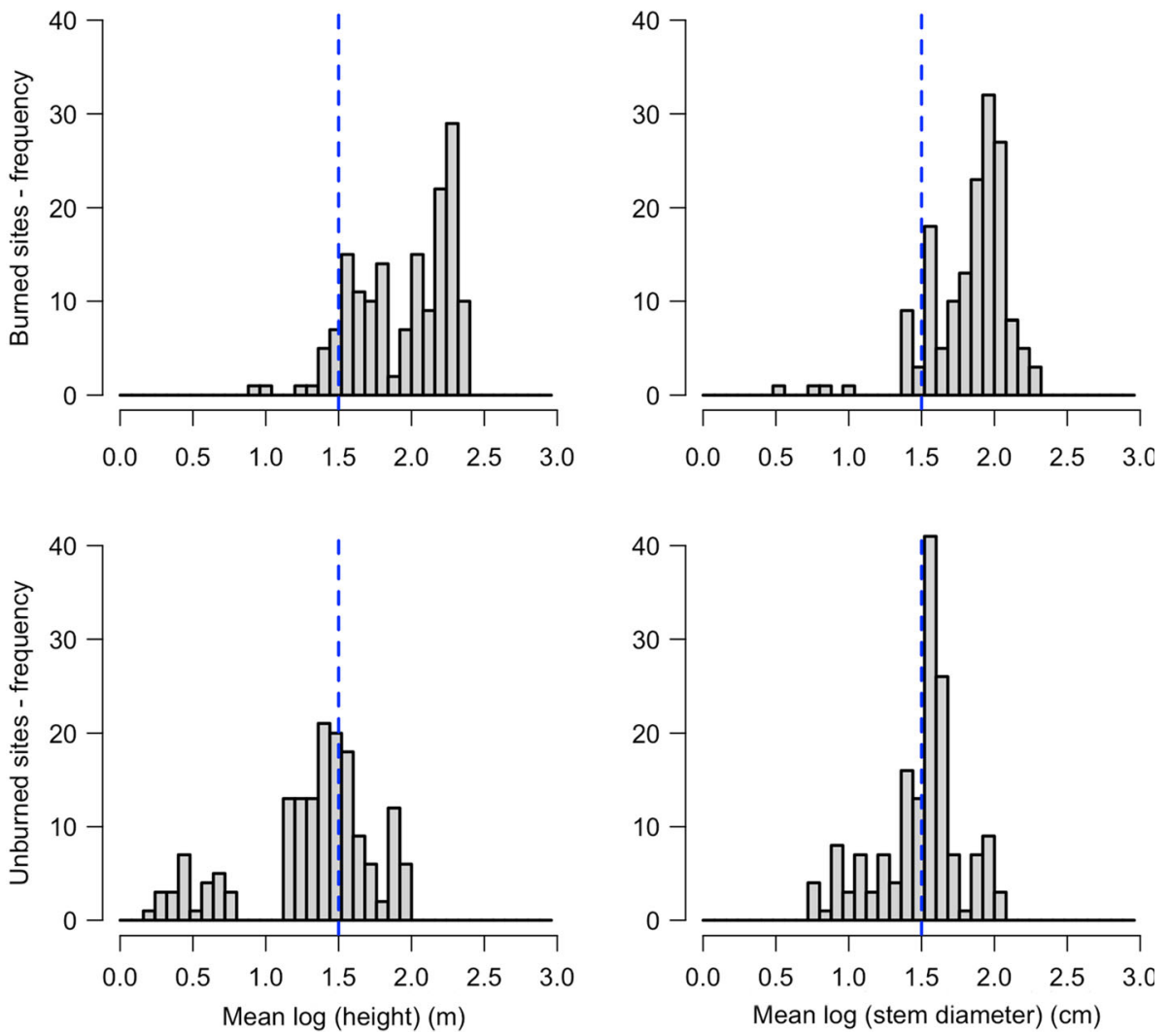
Table 2 Regression analyses of the effect of soil characteristics on diameter and height of $E$. Grandis after fire

Table 3 Regression analyses of the effect of soil characteristics on bark thickness and wood density

\begin{tabular}{|c|c|c|c|c|c|c|c|c|}
\hline \multirow[t]{2}{*}{ Variable } & \multicolumn{4}{|c|}{ Stem diameter } & \multicolumn{4}{|l|}{ Height } \\
\hline & Estimate & SE & $t$ value & $p$ value & Estimate & SE & $t$ value & $p$ value \\
\hline Intercept & 0.204 & 1.167 & 0.175 & 0.862 & 2.890 & 1.658 & 1.743 & 0.090 \\
\hline $\mathrm{Ca}^{2+}$ & 0.183 & 0.031 & 0.622 & 0.711 & -0.616 & 0.007 & -1.022 & 0.081 \\
\hline $\mathrm{Mg}^{2+}$ & 0.021 & 0.001 & 0.394 & 0.092 & 0.803 & 0.032 & 4.181 & $\leq 0.001$ \\
\hline $\mathrm{K}^{+}$ & 0.001 & 0.002 & 0.466 & 0.644 & -0.009 & 0.002 & -3.726 & $\leq 0.001$ \\
\hline Soil pH & -0.162 & 0.338 & -0.479 & 0.635 & -1.890 & 1.480 & -1.277 & 0.058 \\
\hline Organic matter & 0.151 & 0.062 & 2.446 & 0.020 & 0.314 & 0.088 & 3.566 & 0.001 \\
\hline $\mathrm{P}$ & -0.062 & 0.407 & -0.152 & 0.880 & -0.567 & 0.578 & -0.981 & 0.334 \\
\hline Total-N & 3.572 & 0.585 & 6.102 & 0.001 & 2.853 & 0.832 & 3.430 & 0.002 \\
\hline
\end{tabular}

Bold values indicate the significance at $p<0.05$

\begin{tabular}{|c|c|c|c|c|c|c|c|c|}
\hline \multirow[t]{2}{*}{ Variable } & \multicolumn{4}{|c|}{ Bark thickness } & \multicolumn{4}{|c|}{ Wood density } \\
\hline & Estimate & SE & $t$ value & $p$ value & Estimate & SE & $t$ value & $p$ value \\
\hline Intercept & 1.407 & 1.259 & 1.117 & 0.272 & 2.457 & 0.544 & 4.515 & $\leq 0.001$ \\
\hline $\mathrm{Ca}^{2+}$ & 0.333 & 0.203 & 1.640 & 0.603 & -0.082 & 0.052 & -1.577 & 0.682 \\
\hline $\mathrm{Mg}^{2+}$ & 0.405 & 0.388 & 1.044 & 0.809 & -0.099 & 0.081 & -1.222 & 0.829 \\
\hline $\mathrm{K}^{+}$ & 0.002 & 0.002 & 1.291 & 0.205 & -0.002 & 0.001 & -2.907 & 0.006 \\
\hline Soil pH & -0.069 & 0.365 & -0.189 & 0.052 & 0.376 & 0.158 & 2.388 & 0.023 \\
\hline Organic matter & 0.008 & 0.067 & 0.123 & 0.902 & -0.075 & 0.146 & -0.514 & 0.063 \\
\hline $\mathrm{P}$ & -0.315 & 0.439 & -0.717 & 0.478 & -0.090 & 0.041 & -2.195 & 0.014 \\
\hline Total-N & 4.909 & 0.632 & 7.771 & $\leq 0.001$ & 1.615 & 0.273 & 5.918 & $\leq 0.001$ \\
\hline
\end{tabular}

Bold values indicate the significance at $p<0.05$

\section{Effect of fire- induced nutrient changes on tree growth}

The effects of soil nutrient changes after fire on E. Grandis are summarized in the regression analysis output (Tables 2, $3)$. Total-N had a significant effect on diameter $(t=6.10$, $r=0.88, p \leq 0.001$; Table 2); soil organic matter also had a similar effect $(t=2.45, r=0.61, p \leq 0.001$; Table 2). Although $\mathrm{Ca}^{2+}, \mathrm{Mg}^{2+}, \mathrm{K}^{+}$and $\mathrm{P}$ increased relatively after fire, their effect on diameter was insignificant $(p \geq 0.05$; Table 2). Generally, $\mathrm{Ca}^{2+}, \mathrm{Mg}^{2+}$ and $\mathrm{P}$ are limiting nutrients in many Eucalyptus plantations on Acrisol soils (Dell et al. 2001; Merino et al. 2005), similar to the soils in this study. This suggests that the application of fertilizers containing $\mathrm{Ca}^{2+}, \mathrm{Mg}^{2+}$ and $\mathrm{P}$ may not significantly improve growth, but fertilizers containing organic matter and total-N should be encouraged (Merino et al. 2005). Similarly, total-N and organic matter were positively correlated with height (total-N vs height: $t=3.43, r=0.77$, $p \leq 0.01$; organic matter vs height: $t=3.57, r=0.54, p$ $\leq 0.001$; Table 2), i.e., tree height increases with total-N and soil organic matter. The effect of $\mathrm{pH}$ on height was insignificant ( $p \geq 0.05, r=0.04$; Table 2). There was a negative correlation between $\mathrm{K}^{+}$and height after fire $(t=-3.73, r=-0.55, p \leq 0.0001$; Table 2).
Total-N had an effect on bark thickness $(t=7.77$, $r=0.89, p \leq 0.001$; Table 3). Although $\mathrm{pH}$ did not affect bark thickness $(t=-0.19, r=0.17, p \geq 0.05$; Table 3), its effect on wood density was significant $(t=2.39$, $r=0.51, p \leq 0.05$; Table 3$)$. The effect of total-N on wood density was highly significant $(t=5.92, r=0.83, p$ $\leq$ 0.001; Table 3) while the effect of soil organic matter was insignificant $(t=-0.51, \quad r=-0.09, \quad p \geq 0.05$; Table 3). Soil $\mathrm{pH}$ also correlated with wood density $(t=2.39, r=0.51, p \leq 0.05)$. The effect of phosphorus on wood density was significant and correlated negatively ( $t=-2.20, r=-0.75, p \leq 0.014$; Table 3$)$, suggesting that an increase in phosphorus decreases wood density. This is not surprising because phosphorus limitation is known to increase wood density in young E. Grandis (Thomas et al. 2006).

\section{Conclusion}

Burning of accumulated vegetal matter or slash increases soil nutrients and enhances the growth of young E. Grandis. Soil $\mathrm{pH}$ increased towards alkaline levels after burning, supporting the observation that burning forest residues has a liming effect on the soil. This enhanced the availability of 
nutrients. Essential soil nutrient levels, including total-N, increased on burned sites and promoted tree growth However, 3 years after the fire the concentration of these elements declined, possibly due to leaching and to the rapid uptake of nutrients by the growing Eucalyptus. Further research considering the status of soil nutrients as well as the pattern of tree growth beyond 3 years could make a significant contribution to the optimization of fertilizer application and other silvicultural practices that can improve soil nutrient status and support growth of $E$. Grandis. Since burning residues increases plant growth, putting slash in piles should therefore be avoided in order to have even distribution of nutrients in the planting area.

Acknowledgements We thank Zambia Forestry and Forest Industries Corporation (ZAFFICO) for access to the company's plantations and for support during sampling. The Copperbelt University is acknowledged for financial support.

Open Access This article is distributed under the terms of the Creative Commons Attribution 4.0 International License (http://creative commons.org/licenses/by/4.0/), which permits unrestricted use, distribution, and reproduction in any medium, provided you give appropriate credit to the original author(s) and the source, provide a link to the Creative Commons license, and indicate if changes were made.

\section{References}

Achat DL, Deleuze C, Landmann G, Pousse N, Ranger J, Augusto L (2015) Quantifying consequences of removing harvesting residues on forest soils and tree growth: a meta-analysis. For Ecol Manage 348:124-141

Adamchuk VI, Morgan MT, Ess DR (1999) An automated sampling system for measuring soil $\mathrm{pH}$. Trans ASAE 42:885-892

Alcañiz M, Outeiro L, Francos M, Úbeda X (2018) Effects of prescribed fires on soil properties: a review. Sci Total Environ 613:944-957

Andersson S, Nilsson SI, Saetre P (2000) Leaching of dissolved organic carbon (DOC) and dissolved organic nitrogen (DON) in mor humus as affected by temperature and $\mathrm{pH}$. Soil Biol Biochem 32:1-10

Antoine V, Yann N, Jean-Paul L, Antoine K, Louis M, Bernd Z, Jacques R, Daniel E (2013) The manipulation of organic residues affects tree growth and heterotrophic $\mathrm{CO}_{2}$ efflux in a tropical Eucalyptus plantation. For Ecol Manage 301:79-88

Arocena JM, Opio C (2003) Prescribed fire-induced changes in properties of subboreal forest soils. Geoderma 113:1-16

Bhat KM, Bhat KV, Dhamodaran TK (2007) Wood density and fiber length of Eucalyptus grandis grown in Kerala, India. Wood Fiber Sci 22:54-61

Boerner RE, Huang J, Hart SC (2009) Impacts of Fire and Fire Surrogate treatments on forest soil properties: a meta-analytical approach. Ecol Appl 19:338-358

Bond WJ, Keeley JE (2005) Fire as a global 'herbivore': the ecology and evolution of flammable ecosystems. Trends Ecol Evol 20:387-394

Bray RH, Kurtz LT (1945) Determination of total organic and available forms of phosphorus in soils. Soil Sci 59:39-45

Bremner JM (1960) Determination of nitrogen in soil by the Kjeldahl method. J Agric Sci 55:11-33

Carrillo I, Aguayo MG, Valenzuela S, Mendonça RT, Elissetche JP (2015) Variations in wood anatomy and fiber biometry of
Eucalyptus globulus genotypes with different wood density. Wood Res 60:1-10

Certini G (2005) Effects of fire on properties of forest soils: a review. Oecologia 143:1-10

Clark B (2001) Soils, water and watersheds. In: Miller M (ed) Fire effects guide. National Interagency Fire Center, Boise, pp 93-109.

de Dieu Nzila J, Bouillet JP, Laclau JP, Ranger J (2002) The effects of slash management on nutrient cycling and tree growth in Eucalyptus plantations in the Congo. For Ecol Manage 171:209-221

DeBell DS, Singleton R, Harrington CA, Gartner BL (2007) Wood density and fiber length in young populus stems: relation to clone, age, growth rate, and pruning. Wood Fiber Sci 34:529-539

Dell B, Malajczuk N, Xu D, Grove TS (2001) Nutrient disorders in plantation eucalypts, 2nd edn. The Australian Center for International Agricultural Research, Canberra, pp 1-188

Fisher R, Binkley D (2000) Ecology and management of forest soils. Wiley, New York, pp 401-489

Fromm J (2010) Wood formation of trees in relation to potassium and calcium nutrition. Tree Physiol 30:1140-1147

González-Pérez JA, González-Vila FJ, Almendros G, Knicker H (2004) The effect of fire on soil organic matter: a review. Environ Int 30:855-870

Graciano C, Guiamet JJ, Goya JF (2005) Impact of nitrogen and phosphorus fertilization on drought responses in Eucalyptus grandis seedlings. For Ecol Manage 212:40-49

Grossman RB, Reinsch TG. (2002). Bulk density and linear extensibility. In: Dane JH, Topp GC (eds.) Methods of soil analysis. Part 4. SSSA Book Ser, 5 edn. SSSA, Madison, pp 208-228

Hart SC, DeLuca TH, Newman GS, MacKenzie MD, Boyle SI (2005) Post-fire vegetative dynamics as drivers of microbial community structure and function in forest soils. For Ecol Manage 220:166-184

Heydari M, Rostamy A, Najafi F, Dey DC (2015) Effect of fire severity on physical and biochemical soil properties in Zagros oak (Quercus brantii Lindl.) forests. Iran J For Res 28:95-104

Hubbert KR, Preisler HK, Wohlgemuth PM, Graham RC, Narog MG (2006) Prescribed burning effects on soil physical properties and soil water repellency in a steep chaparral watershed, southern California, USA. Geoderma 130:284-298

Hunt N, Gilkes B (1992) Farm monitoring handbook. The University of Western Australia, Nedlands, pp 1-280

Inbar A, Lado M, Sternberg M, Tenau H, Ben-Hur M (2014) Forest fire effects on soil chemical and physicochemical properties, infiltration, runoff, and erosion in a semi-arid Mediterranean. Geoderma 221:131-138

James JA, Kern CC, Miesel JR (2018) Legacy effects of prescribed fire season and frequency on soil properties in a Pinus resinosa forest in northern Minnesota. For Ecol Manage 415:47-57

Kalbitz K, Solinger S, Park JH, Michalzik B, Matzner E (2000) Controls on the dynamics of dissolved organic matter in soils: a review. Soil Sci 165:277-304

Kemmitt SJ, Wright D, Goulding KW, Jones DL (2006) $\mathrm{pH}$ regulation of carbon and nitrogen dynamics in two agricultural soils. Soil Biol Biochem 38:898-911

Khanna PK, Raison R, Falkiner R (1994) Chemical properties of ash derived from Eucalyptus litter and its effects on forest soils. For Ecol Manage 66:107-125

Kim YS, Makoto K, Takakai F, Shibata H, Satomura T, Takagi K, Hatano R, Koike T (2011) Greenhouse gas emissions after a prescribed fire in white birch-dwarf bamboo stands in northern Japan, focusing on the role of charcoal. Eur J Forest Res 130:1031-1044 
King DA, Davies SJ, Tan S, Noor NSM (2006) The role of wood density and stem support costs in the growth and mortality of tropical trees. J Ecol 94:670-680

Knapp AK, Seastedt TR (1986) Detritus accumulation limits productivity of tallgrass prairie. Bioscience 36:662-668

Ko JH, Kim WC, Cho JS, Choi YI, Park EJ, Im JH, Han O, Keathley D, Han KH (2017) EliteTree ${ }^{\mathrm{TM}}$ : an advanced biomass tree crop technology that features greater wood density and accelerated stem growth. Biofuels, Bioprod Biorefin 11:521-533

Lawes MJ, Clarke PJ (2011) Ecology of plant resprouting: populations to community responses in fire-prone ecosystems. Plant Ecol 212:1937-1943

Martin DA, Moody JA (2001) Comparison of soil infiltration rates in burned and unburned mountainous watersheds. Hydrol Process 15:2893-2903

Mehlich A (1984) Mehlich 3 soil test extractant: a modification of Mehlich 2 extractant. Commun Soil Sci Plant Anal 15:1409-1416

Merino A, Balboa MA, Soalleiro RR, Gonzalez JA (2005) Nutrient exports under different harvesting regimes in fast-growing forest plantations in southern Europe. For Ecol Manage 207:325-339

Murphy JD, Johnson DW, Miller WW, Walker RF, Carroll EF, Blank RR (2006) Wildfire effects on soil nutrients and leaching in a Tahoe Basin Watershed. J Environ Qual 35:479-489

Nabatte P, Nyombi K (2013) Effect of pine plantation surface fires on soil chemical properties in Uganda. Res J Agric For Sci 1:10-14

Neff JC, Harden JW, Gleixner G (2005) Fire effects on soil organic matter content, composition and nutrients. Can J For Res $35: 2178-2187$

Ojima DS, Schimel DS, Parton WJ, Owensby CE (1994) Long-and short-term effects of fire on nitrogen cycling in tallgrass prairie. Biogeochemistry 24:67-84

Otterstrom SM, Schwartz MW, Velázquez-Rocha I (2006) Responses to fire in selected tropical dry forest trees 1. Biotropica 38:592-598

Paine CET, Stahl C, Courtois EA, Patiño S, Sarmiento C, Baraloto C (2010) Functional explanations for variation in bark thickness in tropical rain forest trees. Funct Ecol 24:1202-1210

Parro K, Köster K, Jõgiste K, Seglinš K, Sims A, Stanturf JA, Metslaid M (2019) Impact of post-fire management on soil respiration, carbon and nitrogen content in a managed hemiboreal forest. J Environ Manage 233:371-377

Pellegrini AF, Ahlström A, Hobbie SE, Reich PB, Nieradzik LP, Staver AC, Scharenbroch BC, Jumpponen A, Anderegg WR, Randerson JT, Jackson RB (2018) Fire frequency drives decadal changes in soil carbon and nitrogen and ecosystem productivity. Nature 553(7687): 194

Pietri JA, Brookes PC (2008) Relationships between soil pH and microbial properties in a UK arable soil. Soil Biol Biochem 40:1856-1861

Pretzsch H, Biber P, Schütze G, Kemmerer J, Uhl E (2018) Wood density reduced while wood volume growth accelerated in Central European forests since 1870. For Ecol Manage 429:589-616

Pyne SJ (2001) Fire: A brief history. University of Washington Press, Seattle, pp 1-224

Quilhó T, Pereira H (2001) Within and between-tree variation of bark content and wood density of Eucalyptus globulus in commercial plantations. Lawa J 22:255-265

Rout G, Samantaray S, Das P (2001) Aluminium toxicity in plants: a review. Agronomie 21:3-21

Sanchez PA (2019) Properties and management of soils in the tropics. Cambridge University Press, Cambridge, pp 433-464

Santana NA, Morales CAS, Silva DAAD, Antoniolli ZI, Jacques RJS (2018) Soil biological, chemical, and physical properties after a wildfire event in a Eucalyptus forest in the Pampa Biome. Revista Brasileira de Ciência do Solo 42:1

Santín C, Otero XL, Doerr SH, Chafer CJ (2018) Impact of a moderate/ high-severity prescribed eucalypt forest fire on soil phosphorous stocks and partitioning. Sci Total Environ 621:1103-1114

Saranpää P (2003) Wood density and growth. In: Barnett JR, Jeronimidis G (eds) Wood quality and its biological basis. Blackwell, Oxford, pp 87-117

Shakacite O, Chungu D, Ng'andwe P, Chendauka B, Siampale A, Tavani R, Roberts W, Vesa L (2016) Integrated land use assessment phase II-report for Zambia. Lusaka, Zambia: Government Printers (The Food and Agriculture Organization of the United Nations and the Forestry Department, Ministry of Lands and Natural Resources), pp 55-80

Simard DG, Fyles JW, Paré D, Nguyen T (2001) Impacts of clearcut harvesting and wildfire on soil nutrient status in the Quebec boreal forest. Can J Soil Sci 81:229-237

Sopushynskyy I, Kharyton I, Teischinger A, Mayevskyy V, Hrynyk H (2017) Wood density and annual growth variability of Picea abies (L.) Karst. growing in the Ukrainian Carpathians. Eur J Wood Wood Prod 75:419-428

Sotelo Montes C, Weber JC, Abasse T, Silva DA, Mayer S, Sanquetta CR, Muñiz GI, Garcia RA (2017) Variation in fuelwood properties and correlations of fuelwood properties with wood density and growth in five tree and shrub species in Niger. Can J For Res 47:817-827

Thomas DS, Montagu KD, Conroy JP (2006) Why does phosphorus limitation increase wood density in Eucalyptus grandis seedlings? Tree Physiol 26:35-42

Thomaz EL, Antoneli V, Doerr SH (2014) Effects of fire on the physicochemical properties of soil in a slash-and-burn agriculture. CATENA 122:209-215

Tng DY, Janos DP, Jordan GJ, Weber E, Bowman DM (2014) Phosphorus limits Eucalyptus grandis seedling growth in an unburnt rain forest soil. Front Plant Sci 5:527

Tomkins IB, Kellas JD, Tolhurst KG, Oswin DA (1991) Effects of fire intensity on soil chemistry in a eucalypt forest. Soil Res 29:25-47

Turner J, Lambert MJ (1983) Nutrient cycling within a 27-year-old Eucalyptus grandis plantation in New South Wales. For Ecol Manage 6:155-168

Turner CL, Blair JM, Schartz RJ, Neel JC (1997) Soil N and plant responses to fire, topography, and supplemental $\mathrm{N}$ in tallgrass prairie. Ecology 78:1832-1843

Verma S, Jayakumar S (2012) Impact of forest fire on physical, chemical and biological properties of soil: a review. Proc Int Acad Ecol Environ Sci 2:168-176

Wan S, Hui D, Luo Y (2001) Fire effects on nitrogen pools and dynamics in terrestrial ecosystems: a meta-analysis. Ecol Appl 11:1349-1365

Xue L, Li Q, Chen H (2014) Effects of a wildfire on selected physical, chemical and biochemical soil properties in a Pinus massoniana forest in south China. Forests 5:2947-2966

Yafei Y, Shengzuo F, Ye T, Shiping D, Luozhong T, Chuong DN (2015) Influence of tree spacing on soil nitrogen mineralization and availability in hybrid poplar plantations. Forests 6:636-649

Yildiz O, Esen D, Karaoz OM, Sarginci M, Toprak B, Soysal Y (2010) Effects of different site preparation methods on soil carbon and nutrient removal from Eastern beech regeneration sites in Turkey's Black Sea region. Appl Soil Ecol 45:49-55

Zhao Y, Wang YZ, Xu ZH, Fu L (2015) Impacts of prescribed burning on soil greenhouse gas fluxes in a suburban native forest of southeastern Queensland, Australia. Biogeosciences 12:6279-6290

Publisher's Note Springer Nature remains neutral with regard to jurisdictional claims in published maps and institutional affiliations. 